\title{
Maya Timeline in Uaxactun: Calendric Notations on the Mural Paintings at Structure B-XIII
}

\author{
JAKUB ŠPOTÁK \\ Department of Comparative Religion \\ Comenius University, Bratislava, Slovakia \\ spotak.jakub@gmail.com
}

\begin{abstract}
Famous Uaxactun Mural paintings, which were found in Structure B-XIII, have been wellknown to Maya scholars for decades. They are considered as proof of Maya-Teotihuacan connection, and the importance of Uaxactun. On the other hand, the different scenes with musicians, nobles and warriors are beautiful source of Maya iconography. Below these paintings, also a short inscription in form of calendric notation was found. This inscription was not analyzed due to imperfect drawing, which was made by Antonio Tejeda in 1930's. Fortunately, it was possible to create a new rendering of this inscription, thanks to preserved photographs of Carnegie Institute.
\end{abstract}

KEY WORDS: Maya, tzolk'in, Uaxactun, Teotihuacan, mural painting, Early Classic

\section{Uaxactun - history, present day, archaeology}

Ancient Maya city Uaxactun has been under archaeological investigation by Center for Mesoamerican Studies (Comenius University) and Slovak Archaeological and Historical Institute (SAHI) since 2009. During excavations in 2009 and 2010, anew stucco mask was discovered in Group H North (KOVÁČ et. al. 2015), identified as astronomical observatory 
(KOVÁČ - KARLOVSKÝ 2015). In 2015, under the direction of Milan Kováč, main excavator Eva Jobbová discovered a ritual cache, hidden deep below the center of the substructure H-XVI Sub. Inside two vessels placed lip-to-lip was found third vessel. It contained a small green stone bead, zoomorphic animal figurine and an anthropomorphic sceptre or perforator covered by beautiful incised hieroglyphs. This Late Preclassic inscription refers to the act of presenting an offering with ritual context and evident blood symbolism (KOVÁČ et al. 2016:9-25).

Previously, the excavations at Uaxactun were carried out by Carnegie Institution of Washington between 1926 and 1937 and it was one of the first large-scale excavations in the Maya area (BLACK 1990:257). Probably the most useful tool, besides other archaeological field methods and approaches (BLACK 1990:257), the ceramic typology and chronological sequence was established. ${ }^{1}$ The Early Classic period of Uaxactun was defined as Tzakol ceramic complex by Smith and moreover, during Tzakol 3 in particular, we can see a sub complex with clear Teotihuacan affiliations (STUART 2000:467).

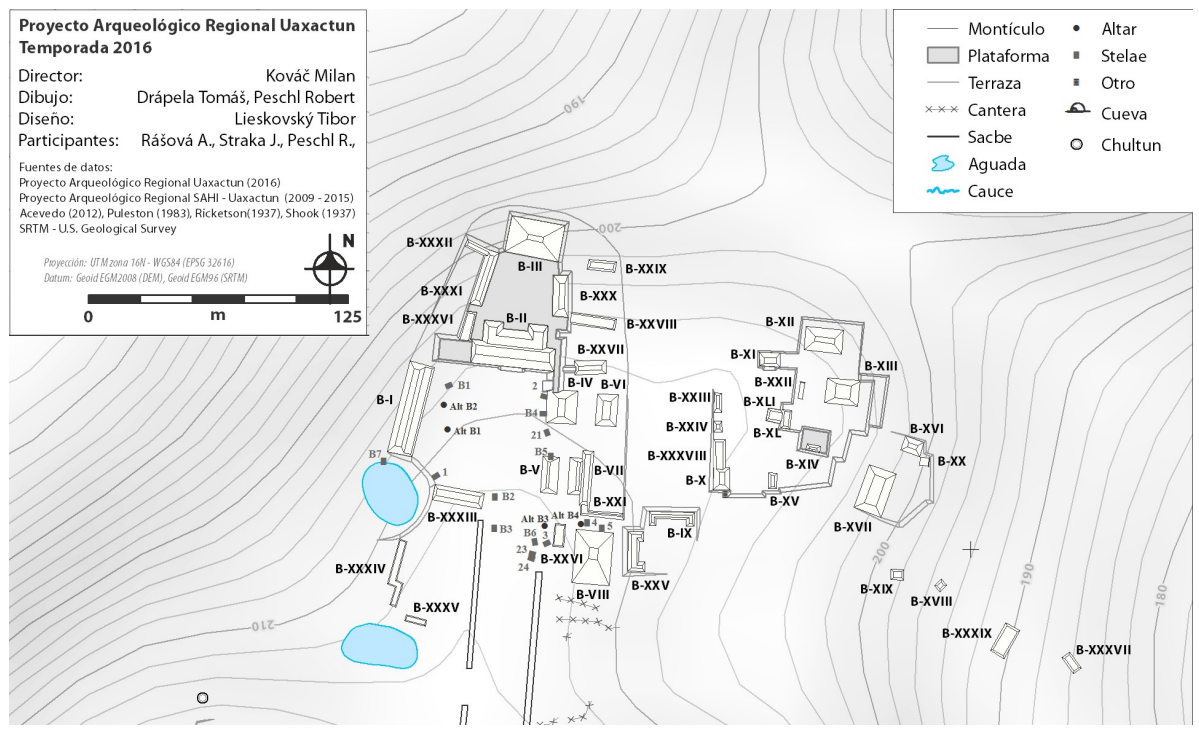

Figure 1: Map of Uaxactun Group B. Structure B-XIII is located on the east plaza. Photo: T. Lieskovský

$1 \quad$ For more information, see SMITH 1955.

DOI: 10.1515/eas-2017-0009 @ University of SS. Cyril and Methodius in Trnava. All rights reserved. 


\section{Teotihuacan and the Maya ${ }^{2}$}

We can track developed trade routes of obsidian between Maya and Teotihuacan in the early $3^{\text {rd }}$ century CE. Some local versions of talud-tablero ${ }^{3}$, clearly of Mexican design, emerged at Tikal at the same time. But at the end of the $4^{\text {th }}$ century these influences had risen. Tatiana Proskouriakoff (1993) named connection between Teotihuacan and Maya as "arrival of strangers", or the invasion of a "foreign army" (MARTIN - GRUBE 2008:29; COWGILL 2003). David Stuart also proposed that the mentioned arrival was a highly disruptive and violent occasion (STUART 2000:489), which was proved by numerous epigraphic and iconographic sources.

The Calendar Round date $11 \mathrm{~Eb} 15 \mathrm{Mak}$, or January 15, $378 \mathrm{CE}$ is probably the most resonating date in the Maya history. Arrival of a lord called Sihyaj K'ahk' on this day to Tikal brought this city and whole Central Area into the political, cultural and economic sphere of Teotihuacan. This is often also called the New Order in the Peten area. Signs of Teotihuacan intrusion are clearly recognizable at cities like Kaminaljuyu, Tikal, La Sufricaya, or Uaxactun. Foreign lord Sihyaj K'ahk' presided over kingly installations at Tikal, Bejucal and probably also at Río Azul (MARTIN - GRUBE 2008:29-30). Sihyaj $\mathrm{K}^{\prime}$ 'ahk' appears also on unprovenanced Late Classic ceramic vessel ${ }^{4}$, depicting two figures which represents warriors in Teotihuacan war costumes. Here, Sihyaj K'ahk' is titled as ch'ajoom, which is common title, and is associated with important toponym - $\mathrm{Wi}^{\text {‘ }} \mathrm{Te}^{\text {c }}$ Naah, or as Alexandre Tokovinine suggested - Wiin Te' Naah (ESTRADA-BELLI TOKOVININE 2016:159-161). It is probably the only portrait of Sihyaj K'ahk' recorded in Maya Art (BELIAEV et. al. 2017:3-4). ${ }^{5}$ Other, more powerful title, which was often part of Sihyaj K'ahk' name, was kalomte' (STUART 2000:476).

The second very important person of the so-called entrada event was Spearthrower Owl (in Maya probably Jatz'om K'uy). A Mexican weapon, called atl-atl, or spearthrower, was part of his name, and it was also a typical part of Mexican iconography in the Maya area. For example, on carved vessel found in Tikal, we can see Teotihuacan army marching into the

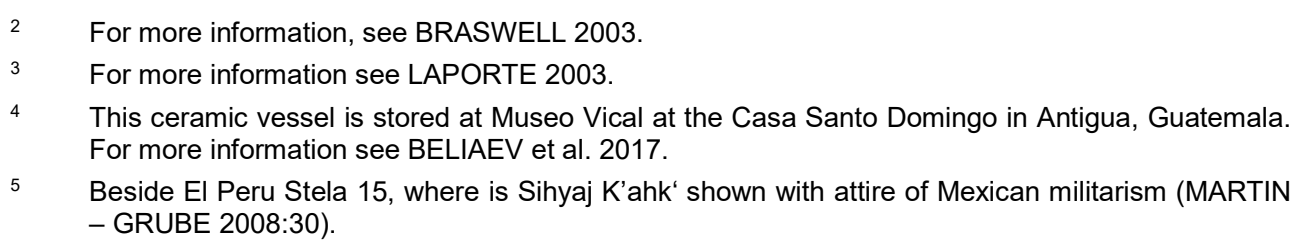

DOI: 10.1515/eas-2017-0009 C University of SS. Cyril and Methodius in Trnava. All rights reserved. 
Maya area (MARCUS 2003:340). Warriors are armed with spears and atl-atl's. Similar examples of Mexican armor are shown for example on the Tikal Stela 31, or on mural paintings at Structure B-XIII in Uaxactun. Also, the figure on Uaxactun Stela 5 is depicted with Teotihuacan armor and date at the inscription reference to a well-known $11 \mathrm{~Eb} 15 \mathrm{Mak}$ event (Figure 2).

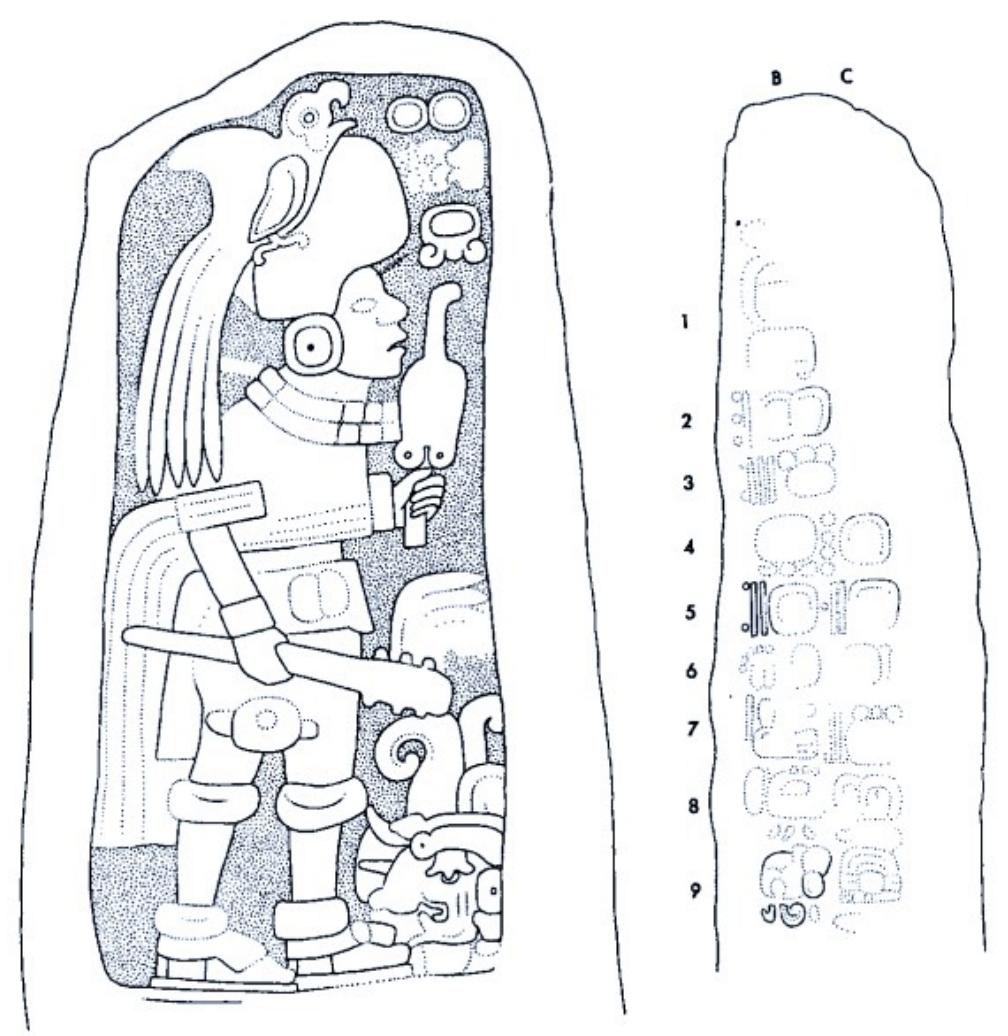

Figure 2: Uaxactun Stela 5 depict Teotihuacan style warrior. Left side of stela recording famous entrada event. Drawing: I. Graham

After the death of Chak Tok Ich'aak I., on the very same date as the arrival of foreign lord Sihyaj K'ahk' (January 15, $378 \mathrm{CE}$ ), a new king was set to throne. It was not Sihyaj K'ahk', or Jatz'om K'uy, but rather the son of the second one, Yax Nuun Ahiin I. 
(MARTIN - GRUBE 2008:32). Various Early Classic Maya dynasties emphasized connections to Sihyaj K'ahk' to legitimate their power (BELIAEV et. al. 2017:3).

It is clear that the heart of Central Maya lowlands was highly influenced by foreign visitors from Teotihuacan. However, this Mexican superpower had a big part in the history of another region and the city Copán, with an important figure - K'ihnich Yax K'uk' Mo' (STUART 2000:490-494).

There are two important inscriptions dealing with entrada events or with the connection between Teotihuacan and Maya. The first one is the so-called Tikal Marcador (Figure 3) and the second one is Tikal Stela 31. Other important information, which supplies previous monumental inscriptions, can be found on Tikal Stela 4. It includes a couple of events, which are in close connections with ruler Yax Nuun Ahiin, the son of Spearthrower Owl (ESTRADA-BELLI et. al. 2009:242-243).

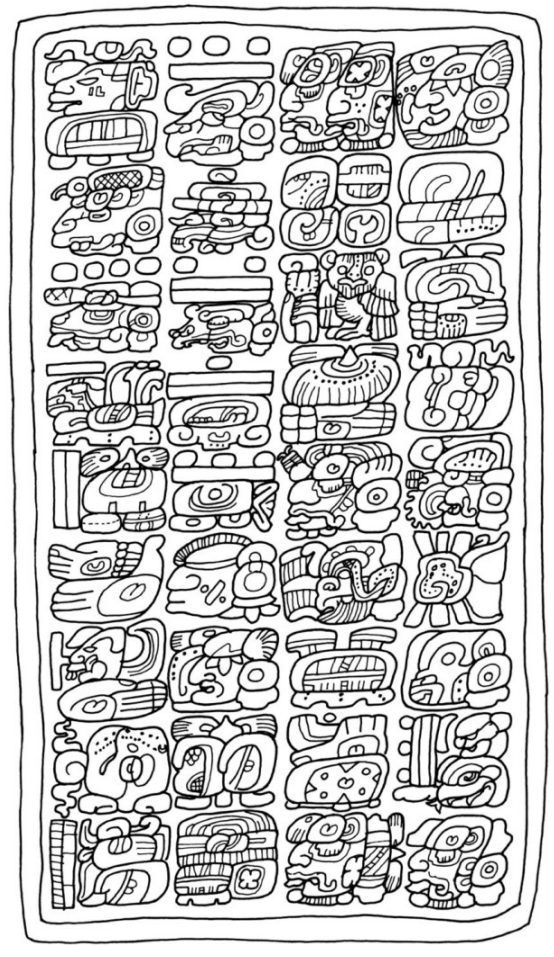

Figure 3: First part of Tikal Marcador, which recorded famous entrada event happened at 11 Eb 10 Mak. Drawing: L. Schele

DOI: 10.1515/eas-2017-0009 C University of SS. Cyril and Methodius in Trnava. All rights reserved. 


\section{Mural paintings in the Maya area}

Mural paintings are a common way of expressing religious, historical or mythological events. They show aspects of society both sacred and profane and they are mostly related to rulers and gods (URQUIZÚ - HURST 2011:8).

\section{La Sufricaya}

The most suitable example of mural paintings in the Central Lowlands are those from Holmul area. Archaeological site known as La Sufricaya is located in the north-eastern Peten, Guatemala. In the Structure 1, which is located on the main platform, several rooms can be found. Room 1 and Room 2 contains mural paintings. Subsequent conservation and analysis of the paintings led to the identification of several Teotihuacan-style figures. Furthermore, hieroglyphic inscriptions link the site to a significant event - the arrival of Teotihuacans in Tikal in 378 CE (ESTRADA-BELLI et. al. 2009:232-234).

Mural 9 consist of two sitting figures. One of them is elderly god, probably God D Itzamnaaj and the second one is anthropomorphic figure with a bird head. The text between these two figures is clearly in Early Classic form, but in a very bad condition. Beside paintings, graffiti in form of Mexican warrior with spears were found (ESTRADA-BELLI et. al. 2009:235-238). These were probably made during a different occasion and time.

Mural 7 has been long known to scholars, because of its direct connection to entrada events. Used color is mostly black for glyphs, with an exception for cartouches of day names. Calligraphic style of the text pertains to Early Classic period, which is characterized by irregular contours of signs and flourishes (ESTRADA-BELLI et. al. 2009:239).

\section{Xultun}

One of the most recent discoveries among mural paintings comes from another important Classic Maya site of Xultun. Central protagonist is ruler named Yax We'nel Chan K'inich, who presents a ritual associated with New Year ceremony (SATURNO et. al. 2017).

Some figures in the scene are labeled with title taaj, which means "obsidian". These mural paintings are located in Structure 10K2 of the Los Sabios Group, which was identified as a residence and workspace for individuals who specialized in astronomical and calendrical knowledge. Individuals that worked at that place probably created mentioned murals and bark-paper codices. These individuals, titled as taaj, were taking care of producing 
ceremonies, performing sacrifices, writing texts, making astronomical observatories or transmitting knowledge (SATURNO et. al. 2017:1-2).

Astronomical tables consisting of lunar table, ring number and the numerical array are also a part of this mural. The first and last mentioned parts are poorly preserved, but easily reconstructable. These mural paintings provided remarkable information of Classic Maya astronomy and calendrical practice (ZENDER - SKIDMORE 2012:1-16).

\section{San Bartolo}

Mural paintings of San Bartolo are located in Structure 1, recently known as the Pyramid of the Paintings. Its substructure contained the mentioned murals, which were partially covered by the construction fill of the final building. After archeological excavations and analysis of painted figures, this mural can be dated to a time period between 200 and 100 BC, clearly into Late Preclassic period (URQUIZÚ - HURST 2011:8-9). The style of San Bartolo's mural paintings is very similar to those in Tikal (Structure 5D-Sub10-1) and Uaxactun (façade of palace structure H-Sub 5).

\section{Ek' Balam}

Archaeological site of Ek' Balam is chronologically and spatially the outermost of those previously mentioned. It is located in the northeastern Yucatán and the culmination of city population happened during Late and Terminal Classic period (VOß - EBERL 1999:124).

The most important example considered in this paper is the mural painting located at Structure 1 (Acropolis) in Room 29-sub, on northeastern inner wall. It is known as the Mural of the 96 Glyphs (Figure 6) and dedication dates are 9.16.19.3.12 $11 \mathrm{~Eb}^{\prime} 10 \mathrm{Sotz}$ (April 7, $770 \mathrm{CE}$ ) and 9.16.19.6.1 8 Imix 19 Xul (May 26, $770 \mathrm{CE}$ ).

\section{Group B - structure B-XIII}

Group B represents the second largest group at Uaxactun (Figure 1). It was defined and excavated during archaeological project of Carnegie Institution of Washington between 1931 and 1937 (SMITH 1950). Western part of the group is directly connected to Group A by causeway, which begins at the Main Plaza next to ballcourt B-V and on the other side from Main Aguada. The important part of the city, which is considered in this paper, is 
eastern part of Group B, containing a small plaza, rounded by structures B-XII, B-XI, BXXII, B-XLI, B-XL, B-XIV and B-XIII, which was probably the main building of this plaza. Unlike other parts of Group B, Eastern plaza does not contain any stone monuments.

According to Carnegie Institute, during Early Classic period, Group B with Group A became a new center of Uaxactun. This location was probably not occupied during the Early Preclassic Period, since no Mamom pottery was found (SMITH 1950:50-51).

Structure B-XIII has three main constructive phases. During the first phase (Phase A) Rooms 1-5 with platform were built; during the second phase (Phase B) Rooms 6-10 were added, together with stairway on the east side leading to Room 7. During phase C, all previous structures were covered by terraced platform, and stairway on west and new Rooms 11-14 were added. As it was mentioned, Room 7, which contains aforementioned mural paintings above and next to the bench, was built during the second phase. It was discovered at the end of the 1937 field season (SMITH 1950:52-55).

\section{Mural paintings in Uaxactun}

Interior decorations in the first and second construction phases took the form of wall painting, traces of red paint and graffiti. Mural painting in Room 7 was protected by a fill covered by floor and was found in a good condition. Antonio Tejeda made a copy in color and also in black and white (Figure 4). At the end of the field season (year 1937), the painting was protected against damage, but covering was removed by unknown persons and painting has completely disappeared (SMITH 1950:55-56).

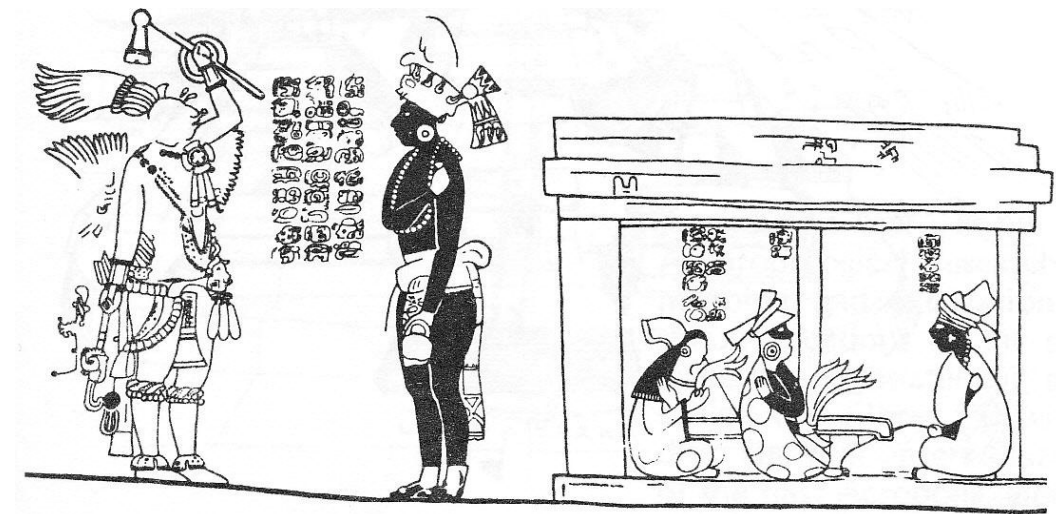

Figure 4: Fragment of famous Uaxactun Mural paintings at Structure B-XIII. Drawing: A. Tejeda

DOI: 10.1515/eas-2017-0009 @ University of SS. Cyril and Methodius in Trnava. All rights reserved. 
According to Mary Ellen Miller (MILLER 2006:65), mural painting, which was found at Structure B-XIII, reveals "sophisticated complexity in $5^{\text {th }}$ century art". Figures are in open space and also within architecture. Musicians are in a dense pack, overlapping one another. A single musician turns to the person behind him with gesture that becomes commonplace in Maya art (MILLER 2006:65). This mural was 3,2m long and 0,9m high, framed by a red band. The type of construction that appeared on the mural was the same as in rooms in phase B. It later served as a model for the archaeological reconstruction (SMITH 1950: 56). Below the main mural painting with iconography, hieroglyphic text in form of alignment of daysigns was discovered.

\section{Schematic layout}

According to J. Eric S. Thompson, hieroglyphic material consisted of a horizontal row of 72 glyphs, representing daysigns of calendar Tzolk'in, starting from 12 Imix and ending with $5 \mathrm{~Eb}$ (SMITH 1950:56).

Thompson also stated that the first day is largely obliterated (SMITH 1950:56), but I doubt that this sign was even painted. It did not even appear on Antonio Tejeda's drawing. I would suggest that whole horizontal timeline started on day 13 Ik'. Therefore, we have 71 daysings in horizontal row. To every sign a number in position as superfix was attached. These were painted in $\mathrm{red}^{6}{ }^{7}$ The reading order is typical left to right.

Unfortunately, neither the photo, nor the Tejeda's drawing show any scale-bar. We do not know the exact measurement of hieroglyphic text, only the dimensions of the whole mural painting. The only possibility is to measure the hieroglyphic text by comparing the dimensions of other object preserved in these photos. In this case, it would be a rectangular niche, whose position is above horizontal row of daysigns and below the main part of mural. Its dimensions are $43 \mathrm{~cm}$ long, $35 \mathrm{~cm}$ high and 30cm deep (SMITH 1950:55).

$6 \quad$ According to analysis of J. Eric S. Thompson in Technical Discussion of the Hieroglyphic Material Below the Wall Painting in Structure B-XIII (SMITH 1950:56-58).

7 Author's analysis of hieroglyphic text was based on grayscale photos of Carnegie Institution of Washington. All photos are accessible through Harvard University's "Visual Information Access" archive. Available here: http://via.harvard.edu:9080/via/deliver/advancedsearch?_collection=via. 
According to this, hieroglyphic text would be approximately $65 \mathrm{~cm}$ long. One daysign is in average $0,90 \mathrm{~cm}$ wide and $1,30 \mathrm{~cm}$ high.

For better orientation, every sign is marked with position number (with start from 13 Ik') and the whole horizontal row is divided into several clauses, which will be discussed later (Figures 8, 9, 10, 11).

$\begin{array}{lll}\text { Clause 1 } & - & \text { position 2 } \\ \text { Clause 2 } & - & \text { position 11 } \\ \text { Clause 3 } & - & \text { position 31 } \\ \text { Clause 4 } & - & \text { position 32 } \\ \text { Clause 5 } & - & \text { position 50 } \\ \text { Clause 6 } & - & \text { position 58 } \\ \text { Clause 7 } & - & \text { position 66 } \\ \text { Clause 8 } & - & \text { position 71 }\end{array}$

All clauses vary between 1 to 8 glyphs and are marked alphabetically (for example glyphs in Clause $31-31 \mathrm{~A}, 31 \mathrm{~B}, 31 \mathrm{C}, \ldots)$

\section{Tzolk'in calendar}

Tzolk'in is a cycle of 260 days, made up of the permutation of 13 numbers and 20 named days. This cycle started on day 1 Imix, the next day will be 2 Ik', 3 Ak'bal and so on (KETTUNEN - HELMKE 2014:49).

Usually, every sign is infixed in a cartouche type glyph with pedestal. There are some exceptions, where the cartouche is missing, for example in Post-Classic codices, or on some painted vessels. The same type appeared also on mural paintings at Structure B-XIII. As a substitute for cartouche, all signs are rounded with $\mathrm{red}^{8}$ circle.

$8 \quad$ According to Thompson (SMITH 1950:56).

DOI: 10.1515/eas-2017-0009 C University of SS. Cyril and Methodius in Trnava. All rights reserved. 


\begin{tabular}{|c|c|c|c|c|c|c|c|c|c|c|c|c|c|}
\hline imix & 1 & 8 & 2 & 9 & 3 & 10 & 4 & 11 & 5 & 12 & 6 & 13 & 7 \\
\hline $\mathrm{ik}^{\prime}$ & 2 & 9 & 3 & 10 & 4 & 11 & 5 & 12 & 6 & 13 & 7 & 1 & 8 \\
\hline ak'bal & 3 & 10 & 4 & 11 & 5 & 12 & 6 & 13 & 7 & 1 & 8 & 2 & 9 \\
\hline k'an & 4 & 11 & 5 & 12 & 6 & 13 & 7 & 1 & 8 & 2 & 9 & 3 & 10 \\
\hline chikchan & 5 & 12 & 6 & 13 & 7 & 1 & 8 & 2 & 9 & 3 & 10 & 4 & 11 \\
\hline kimi & 6 & 13 & 7 & 1 & 8 & 2 & 9 & 3 & 10 & 4 & 11 & 5 & 12 \\
\hline manik' $^{\prime}$ & 7 & 1 & 8 & 2 & 9 & 3 & 10 & 4 & 11 & 5 & 12 & 6 & 13 \\
\hline lamat & 8 & 2 & 9 & 3 & 10 & 4 & 11 & 5 & 12 & 6 & 13 & 7 & 1 \\
\hline muluk & 9 & 3 & 10 & 4 & 11 & 5 & 12 & 6 & 13 & 7 & 1 & 8 & 2 \\
\hline ok & 10 & 4 & 11 & 5 & 12 & 6 & 13 & 7 & 1 & 8 & 2 & 9 & 3 \\
\hline chuwen & 11 & 5 & 12 & 6 & 13 & 7 & 1 & 8 & 2 & 9 & 3 & 10 & 4 \\
\hline$e b$ & 12 & 6 & 13 & 7 & 1 & 8 & 2 & 9 & 3 & 10 & 4 & 11 & 5 \\
\hline ben & 13 & 7 & 1 & 8 & 2 & 9 & 3 & 10 & 4 & 11 & 5 & 12 & 6 \\
\hline ix & 1 & 8 & 2 & 9 & 3 & 10 & 4 & 11 & 5 & 12 & 6 & 13 & 7 \\
\hline men & 2 & 9 & 3 & 10 & 4 & 11 & 5 & 12 & 6 & 13 & 7 & 1 & 8 \\
\hline kib & 3 & 10 & 4 & 11 & 5 & 12 & 6 & 13 & 7 & 1 & 8 & 2 & 9 \\
\hline kaban & 4 & 11 & 5 & 12 & 6 & 13 & 7 & 1 & 8 & 2 & 9 & 3 & 10 \\
\hline etz'nab & 5 & 12 & 6 & 13 & 7 & 1 & 8 & 2 & 9 & 3 & 10 & 4 & 11 \\
\hline kawak & 6 & 13 & 7 & 1 & 8 & 2 & 9 & 3 & 10 & 4 & 11 & 5 & 12 \\
\hline ajaw & 7 & 1 & 8 & 2 & 9 & 3 & 10 & 4 & 11 & 5 & 12 & 6 & 13 \\
\hline
\end{tabular}

Figure 5: Complete 260-day cycle of calendar Tzolk'in with highlighted sequence of days corresponding to "timeline" at the Uaxactun Mural. (KETTUNEN - HELMKE 2014:49; modified by author)

All daysigns and coefficients are in correct order, without any skip or mistake, beginning with $13 \mathrm{Ik}$ ' and ending with $5 \mathrm{~Eb}$ (Figure 5). Analysis of these signs indicates their Early Classic form. It is obvious in some specific daysigns like Ik', Manik', Lamat, Muluk, Eb, Kaban, Etz'nab or Ajaw.

J. Eric Thompson offers enhanced analysis of every daysign of calendar Tzolk'in. ${ }^{9}$ In fact, we can compare some specific daysigns with other Early Classic examples.

$9 \quad$ For more information see SMITH 1950:56-57.

DOI: 10.1515/eas-2017-0009 C University of SS. Cyril and Methodius in Trnava. All rights reserved. 
Table 1: Tzolk'in daysigns in Uaxactun Murals, Structure B-XIII

\begin{tabular}{|l|c|c|c|l|}
\hline & $\begin{array}{c}\text { No. of } \\
\text { examples }\end{array}$ & $\begin{array}{r}\text { No. of preserved } \\
\text { examples }\end{array}$ & $\begin{array}{c}\text { Early Classic } \\
\text { form }\end{array}$ & Positions \\
\hline Imix & 3 & 2 & $X$ & $20,40,60$ \\
Ik' & 4 & 1 & & $01,21,41,61$ \\
Ak'bal & 4 & 2 & & $02,22,42,62$ \\
K'an & $3(4)$ & 1 & & $03,23,(43), 63$ \\
Chikchan & $3(4)$ & 1 & & $04,24,(44), 64$ \\
Kimi & 4 & 2 & $X$ & $05,25,45,65$ \\
Manik' & $3(4)$ & 2 & $X$ & $06,26,(46), 66$ \\
Lamat & 4 & 2 & $X$ & $07,27,47,67$ \\
Muluk & 4 & 2 & & $08,28,48,68$ \\
Ok & 4 & 0 & $X$ & $09,29,49,69$ \\
Chuwen & 4 & 2 & & $10,30,50,70$ \\
Eb & 4 & 2 & & $11,31,51,71$ \\
Ben & 3 & 2 & & $12,32,52$ \\
Ix & 3 & 1 & & $14,33,53$ \\
Men & 3 & 1 & & $15,35,54$ \\
Kib & 3 & 1 & & $16,36,56$ \\
Kaban & 3 & 2 & & $17,37,57$ \\
Etz'nab & 3 & 1 & & $18,38,58$ \\
Kawak & 3 & 0 & & $19,39,59$ \\
Ajaw & 3 & 3 & &
\end{tabular}

\section{$I k^{\prime}$}

Second day in twenty-day cycle of Tzolk'in is typical with T-shape form, representing wind. In the Early Classic (probably during Late Pre-Classic also) sign T23 ${ }^{10}$ (or -na syllable) part of $<$ IK' $>$ was added as a superfix. This kind of daysign was used also in the famous Pre-Classic San Bartolo murals.

10 Classification according to Thompson catalogue (THOMPSON 1962).

DOI: 10.1515/eas-2017-0009 @ University of SS. Cyril and Methodius in Trnava. All rights reserved. 


\section{Lamat}

The sign of this day is preserved only in two cases. They are a little bit different from each other. Both are made from rhomb and circles in four corners. In the first case (position 27), there are dots inside these four circles; on the other hand, at position 67, the dot is inside the rhomb and circles are clean, and it is more similar to the Lamat sign in Post-Classic Dresden codex, page 28. It is Early Classic form of T510 sign. Similar shape can be found in inscriptions from Uaxactun Stela 5, left side (E9).

During Protoclassic period ${ }^{11}$, star signs can appear more flat-sided, like example from La Mojarra Stela 1 (GARTON - TAUBE 2017:37).

\section{Muluk'}

This sign represents probably up-end vessel, which is obvious in positions 48 and 68 . During the Late Classic and Post-Classic, this sign was often reduced only to one dot in the middle.

\section{$\boldsymbol{E b}$}

This sign is in Early Classic form, where only the lower part of head (or skull) is shown, with three or four teeth. It is very similar to daysign $1 \mathrm{~Eb}$ from Leiden plaque, which is dated to $320 \mathrm{CE}$ according to its Long Count date.

\section{Etz'nab}

During the Late Classic, this daysign is often depicted as two crossed lines, which represent probably flint. On Uaxactun Mural, Etz'nab is represented in a form of more complex sign - logogram for "chop" - <CH'AK>. ${ }^{12}$ Similar sign can be seen on Balakbal Stela 5 (SMITH 1955:58), which falls on 8.18.9.17.18 9 Etz'nab 16 Pop (May 14, 406 CE), and by stylistic form it is very close to Uaxactun Mural.

11 Ca. 100 B.C. - A.D. 250.

12 For compare see STONE - ZENDER 2011:57.

DOI: 10.1515/eas-2017-0009 @ University of SS. Cyril and Methodius in Trnava. All rights reserved. 


\section{Ajaw}

This daysign is the most recognizable among other Tzolk'in glyphs. The early form is slightly different from the Late Classic one. It is easily comparable to other sources from the same era and location. For example, on Uaxactun Stela 26, which is dated to $445 \mathrm{CE}$, typical Early Classic T533 form is depicted, almost identical as on the mural at Structure BXIII. Similar Early Classic "Ajaw" sign T533 is shown on the mural painting from Tikal Burial 48 which belongs to Sihyaj Chan K'awiil (MARTIN - GRUBE 2008:36).

Similar hieroglyphic row of daysigns, but in other context, is shown in the Chilam Balam of Chumayel. In the chapter "The Creation of the Winal" is shown recitation of the days and numbers of the Tzolk'in proceeding from day 12(13) Ok to 6 Muluk for a total of twenty days. It represents a narrative, framed as the accomplishments of the first sage, and recapitulates the creation of month and day dames (RICE 2007:32).

This kind of day-by-day record of Tzolk'in sings appears also in Post-Classic codices. Especially in the Madrid Codex, a structural type of almanac which we call as in extenso, can be found for example on pages M.13 - M.18. This term refers to the almanacs that represent all 260 days of the Tzolk'in, rather than just highlighting certain ones (VAIL AVENI 2004:142). But these almanacs were recorded and counted for different purposes and in different contexts. ${ }^{13}$ More closer in form to Uaxactun Mural are painted inscriptions from Ek' Balam (Figure 6). The mural of the 96 Glyphs consists of three rows and 32 columns. The reading order is in horizontal lines (LACADENA 2004:54), after the first event happened at $11 \mathrm{~Eb}^{\prime} 10$ Sotz' (9.16.19.3.12) described at upper row, the text continues from 12 Ben day-by-day until 8 Imix, that means 48 days later. In fact, this type of record serves as an extensive distance number. These are the intervals between dates in the Maya inscriptions (KETTUNEN - HELMKE 2014:50). The most common way is to divide days into cycles, which are same as cycles in Long Count.

13 Very interesting is also example on polychrome plate, labeled as K5379, with figure of Maize God in center. Outer ring is decorated with twenty daysigns of Tzolk'in, arranged in four groups of five signs. This plate is described in STUART 2011:144-145.

DOI: 10.1515/eas-2017-0009 @ University of SS. Cyril and Methodius in Trnava. All rights reserved. 


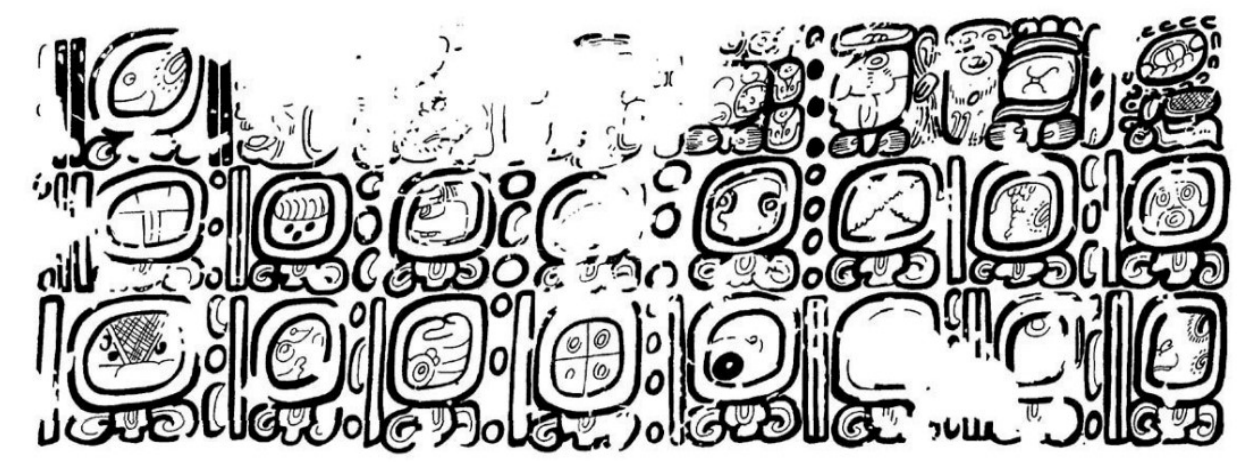

Figure 6: Inscriptions from mural paintings at Room 29, Structure 1, Ek' Balam. Drawing: A. Lacadena

The same principle of extensive distance number as in Ek' Balam was used on Uaxactun mural painting (Tables 3 and 4). As it was mentioned before, the whole sequence started at $13 \mathrm{Ik}$ ' and the first event happened on the next day. After nine days, on $10 \mathrm{~Eb}$, second event happened; and the third event happened after 20 days on $4 \mathrm{~Eb}$. On very next day, after $4 \mathrm{~Eb}$, the fourth event happened on 5 Ben and after 18 days, the fifth event is placed on 10 Chuwen. There is a little possibility of specific event, which could have happened eight days later, on 5 Kawak, but unfortunately, only a fragment of glyph contours was preserved. After another eight days on 13 Manik an event described by longest clause of whole inscription took place. The whole sequence probably ended five days later on $5 \mathrm{~Eb}$, but this part is barely visible.

\section{Epigraphic analysis}

Style of the hieroglyphic signs is clearly Early Classic. It is very simplified in case of Tzolk'in signs. If we look at the inscriptions of sculpture called "Hombre de Tikal", or "Man of Tikal" (FAHSEN 1988:Figure 4; TOKOVININE - SAFRONOV 2016:6), there are very similar patterns of some signs. Probably the most easily recognizable sign is logogram $<$ BAH $>$ on position 66B (with pronominal affix $<\mathbf{u}>$, as $u$ baah). Paleographically speaking, the style of $u$ baah glyph, or for example -na suffixes, are diagnostics of Early Classic style of calligraphy. During the Late Classic, baah glyph was depicted with infixed sign $<\mathbf{K}$ 'AN $>$ (yellow) and during the Late Post-Classic it was labeled with <AK'AB>, which means darkness (STONE - ZENDER 2011:193). The same 
calligraphic style of logogram $<\mathbf{B A H}>$ appears also on a painted stucco vessel from Burial A-31 in Uaxactun (Figure 12).

Painted glyphs are very hard to read. Drawing of Antonio Tejeda, which was made shortly after the discovery of the mural painting, is imperfect and in the most cases based on bad interpretations of signs. The only possibility how to extract more information from inscriptions is the using of preserved photographs with specific filters to make a new rendering (Figure 7).

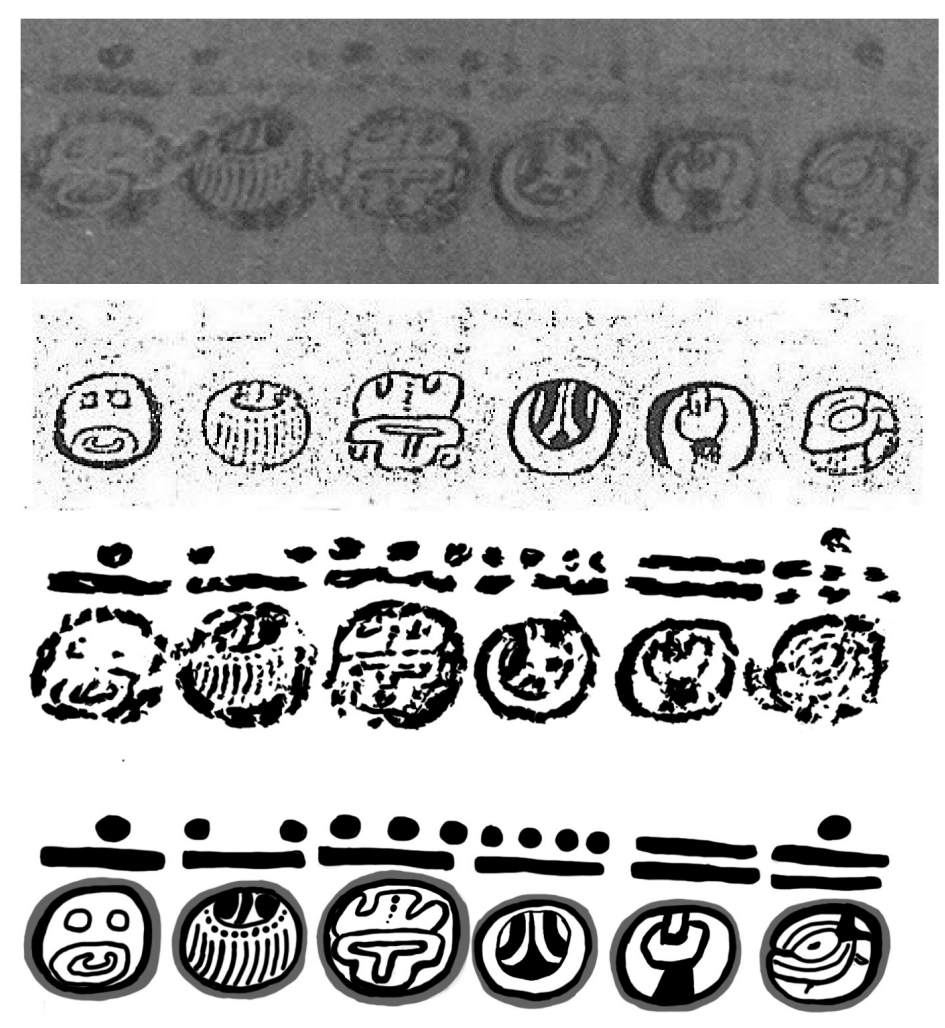

Figure 7: Six successive daysigns in four different renditions:

1. Photography made by Carnegie Institution; 2. Drawing made by Antonio Tejeda; 3. Rendering made by author; 4. Reconstructed version made by author, based on photographs in property of Harvard University's "Visual Information Access" archive. 
We can identify probably eight clauses, under eight daysigns, which probably refers to specific events. Unfortunately, the clauses on positions 2 and 58 are barely visible (Figure 8 and 11). The number of glyphic signs for each column is not uniformed, but the range is between two signs (position 32, 71), three signs (position 11, 50), four signs (position 31) and eight signs for position 66.

The word order for all clauses is not typical. In the Maya hieroglyphic text, and also in the modern Maya languages, the word order usually follows the verb-object-subject pattern (KETTUNEN - HELMKE 2014:24). This is not working for Uaxactun painted murals. None of the first glyphs look like verbs and therefore clauses do not follow typical pattern.

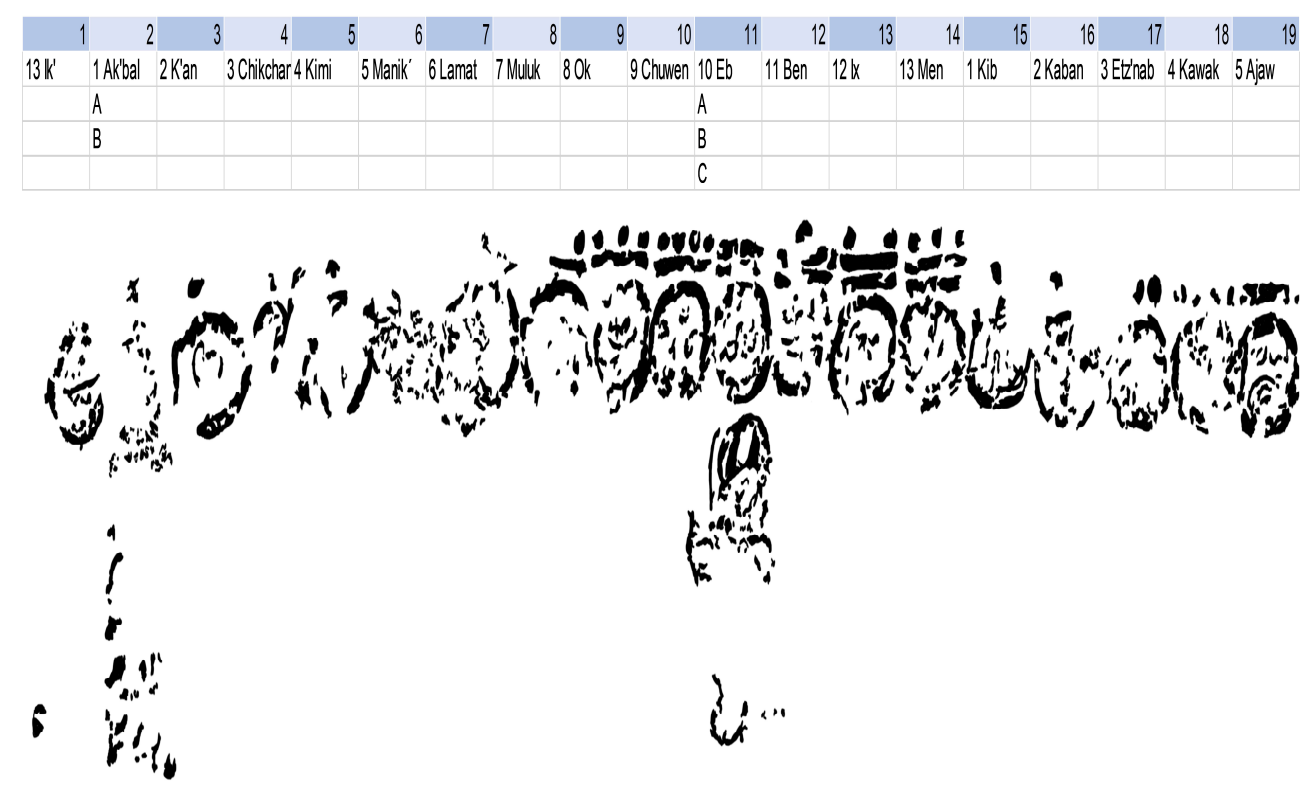

Figure 8: Early Classic "timeline" from Structure B-XIII, Uaxactun from position 1 to 19. Rendering by author, based on photographs in property of Harvard University's „Visual Information Access" archive. 


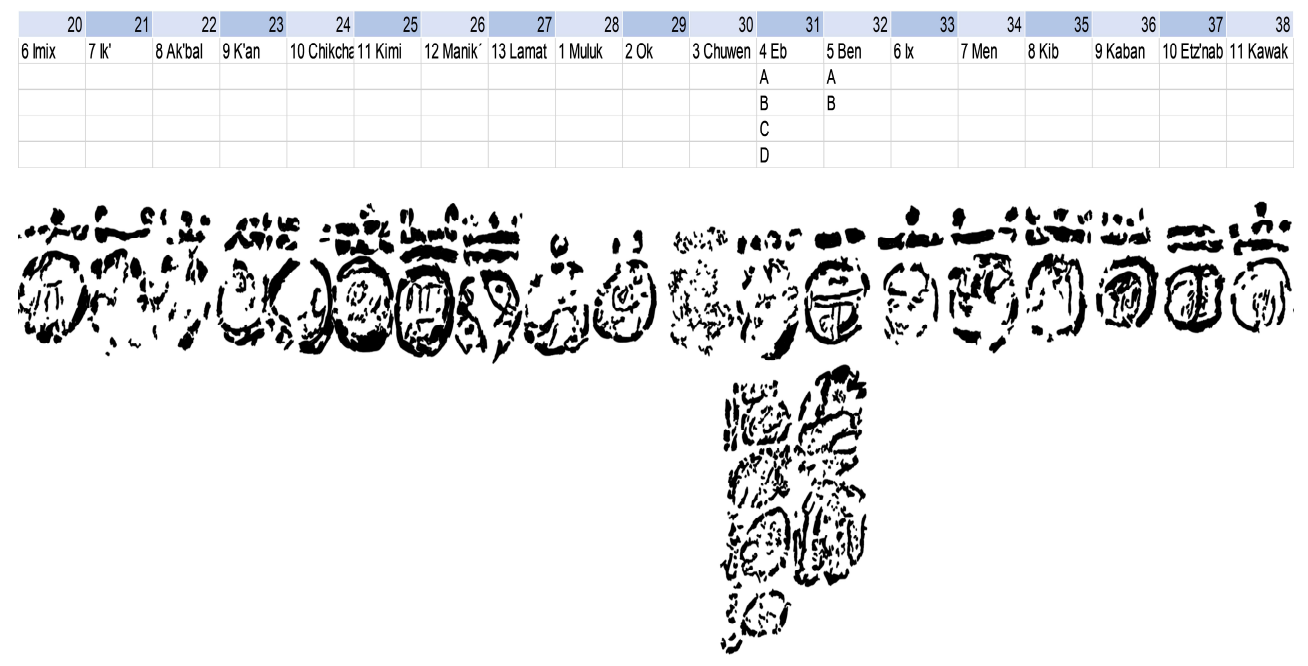

Figure 9: Early Classic "timeline" from Structure B-XIII, Uaxactun from position 20 to 38. Rendering by author, based on photographs in property of Harvard University's „Visual Information Access" archive.

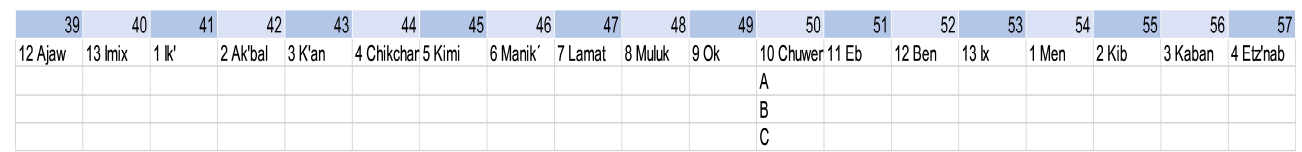

\section{a.

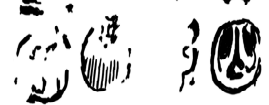

$$
\rightarrow \text { a }
$$

Figure 10: Early Classic "timeline" from Structure B-XIII, Uaxactun from position 39 to 57. Rendering by author, based on photographs in property of Harvard University's „Visual Information Access" archive. 

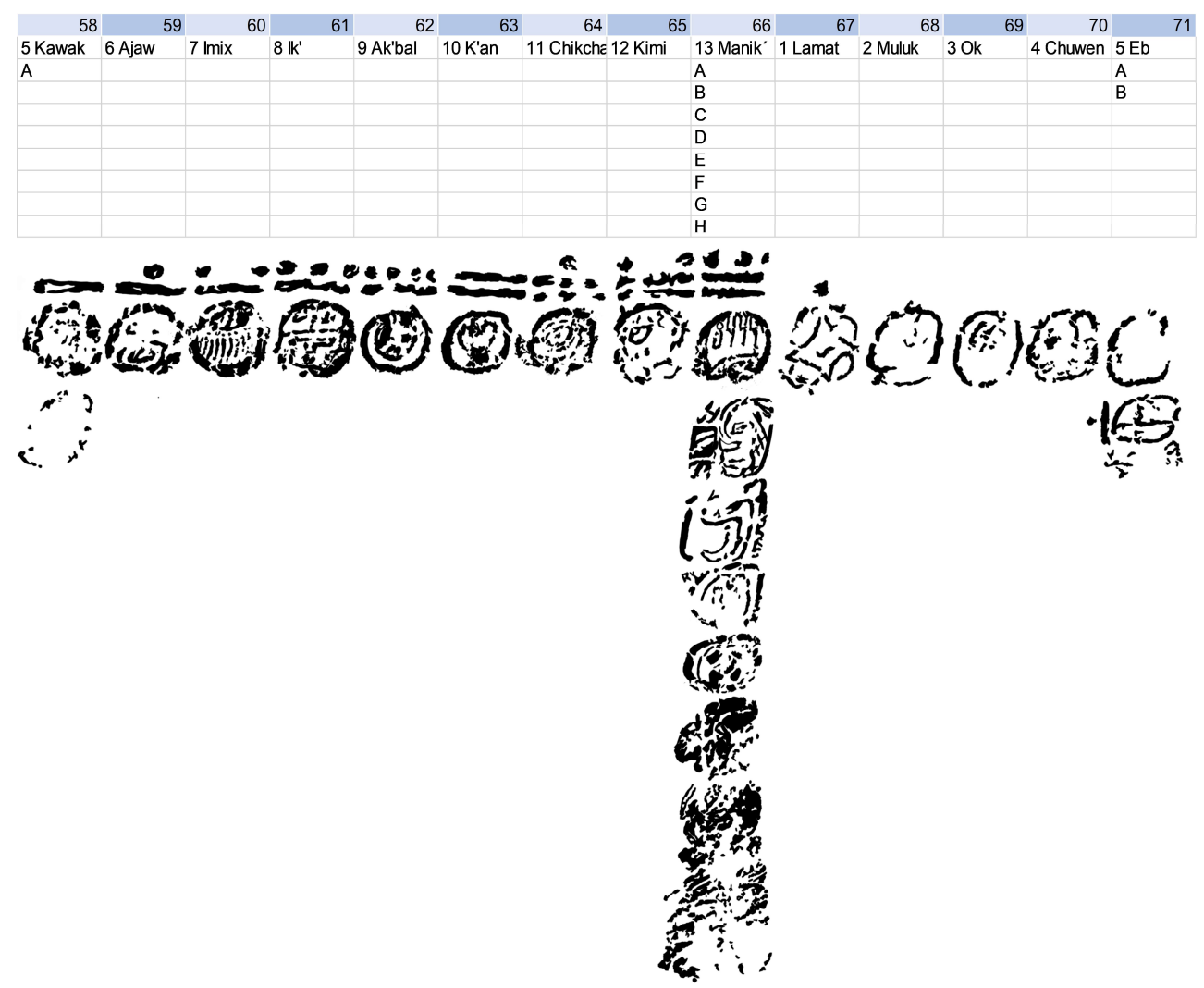

Figure 11: Early Classic "timeline" from Structure B-XIII, Uaxactun from position 58 to 71 . Rendering by author, based on photographs in property of Harvard University's „Visual Information Access" archive.

The reading order is strictly in one column from top to bottom. The only possible uncertainty is on positions 31 and 32, but there is a clear distinction between these two columns in form of different size of glyphs. Similarly, as La Sufricaya Mural 9, blocks in each column were not aligned horizontally with neighboring blocks in other columns. It suggests, that the columns were meant to be read separately from top to bottom, which is a typical pattern found in three other existing Early Classic inscriptions at La Sufricaya. We can see a similar pattern on Mural 7 too (ESTRADA-BELLI et. al. 2009:235-239). 


\begin{tabular}{|c|c|c|c|c|c|c|}
\hline \multirow{2}{*}{$\begin{array}{l}\text { Clause } 1 \text { (pos. 2) } \\
\text { Clause } 2 \text { (pos. 11) }\end{array}$} & \multirow{2}{*}{-} & \multicolumn{3}{|c|}{ unreadable } & \multirow[b]{2}{*}{-} & \multirow[b]{2}{*}{ u?tak } \\
\hline & & $11 \mathrm{~A}$ & - & u?-ta-ka & & \\
\hline & & 11B & - & $?$ & & \\
\hline & & $11 \mathrm{C}$ & - & $?$ & & \\
\hline \multirow[t]{4}{*}{ Clause 3 (pos. 31) } & - & $31 \mathrm{~A}$ & - & X-SAK?/YAX?-SIHOM? & - & $10 ?$ \\
\hline & & 31B & - & AT?-na & - & atan \\
\hline & & $31 \mathrm{C}$ & - & $?$ & & \\
\hline & & $31 \mathrm{D}$ & - & $?$ & & \\
\hline \multirow[t]{2}{*}{ Clause 4 (pos. 32) } & - & $32 \mathrm{~A}$ & - & ta?-ka? & - & tak \\
\hline & & $32 \mathrm{~B}$ & - & LAKAM? & - & lakam \\
\hline \multirow[t]{3}{*}{ Clause 5 (pos. 50) } & - & $50 \mathrm{~A}$ & - & ta-ka & - & tak \\
\hline & & $50 \mathrm{~B}$ & - & AT?-na & - & atan? \\
\hline & & $50 \mathrm{C}$ & - & WINIK?-WINIK? & - & $?$ \\
\hline Clause 6 (pos. 58) & - & \multicolumn{3}{|c|}{ unreadable } & & \\
\hline \multirow[t]{8}{*}{ Clause 7 (pos. 66) } & - & $66 \mathrm{~A}$ & - & $?$ & & \\
\hline & & $66 \mathrm{~B}$ & - & u-BAAH & - & ubaah \\
\hline & & $66 \mathrm{C}$ & - & ?-WINIK? & & \\
\hline & & $66 \mathrm{D}$ & - & $?$ & & \\
\hline & & $66 \mathrm{E}$ & - & $?$ & & \\
\hline & & $66 \mathrm{~F}$ & - & ta?-ka? & - & tak? \\
\hline & & $66 G$ & - & ma?-? & & \\
\hline & & $66 \mathrm{H}$ & - & $?$ & & \\
\hline \multirow[t]{2}{*}{ Clause 8 (pos. 71) } & & $71 \mathrm{~A}$ & - & VI-HAB & - & wak haab \\
\hline & & 71B & - & $?$ & & \\
\hline
\end{tabular}

\section{Haab calendar}

The Tzolk'in calendar is a cycle of 260 days, made up of the permutation of thirteen numbers and twenty named days (KETTUNEN - HELMKE 2014:49). In the Maya inscriptions, it is often paired with other cycle named Haab, which is a 365-day calendar, 
and together they create Calendar Round. This calendar is based on a solar year, and it is organized in 18 "months" of twenty days with one additional 5-day month, called Wayeb.

One day in Tzolk'in repeats every 260 days, but a certain combination with Haab calendar gives us repeat roughly every 52 years. For non-historical records, such as almanacs in the Post-Classic codices, it was no need to apply date in the Haab calendar, because prophecies were made only for specific Tzolk'in days and intervals.

In the inscriptions below the line of Tzolk'in days, there is probably only one possibility of a record of the Haab date. On position 31, below $4 \mathrm{~Eb}$ date, we can see a glyph with number 10 on right side. In combination of dates of two calendars, one needs to follow the rule of possible Haab coefficients for Tzolk'in day names (KETTUNEN - HELMKE 2014:51). For day Eb it is 5, 10, 15 and 0, which would be correct in case of possible Calendar round that appeared in Uaxactun Mural.

Between 8.16.0.0.0 and 9.5.0.0.0, there are totally 61 possible dates of combination $4 \mathrm{~Eb}$ 10? (Table 2). We can eliminate too early and late dates, if we take into account the archaeological data of possible date of structure B-XIII and also the style of hieroglyphic signs. Therefore, the first possible date would be 8.16.10.06.12 4 Eb 10 Kumk'u (April 24, $367 \mathrm{CE}$ ) and probably the latest date would be 9.0.03.05.12 4 Eb $10 \mathrm{~K}$ 'ayab (March 17, 439 $\mathrm{CE})$. Still, between these two dates, we have 24 possible matches.

Table 2: Possible dates for position 31 with 4 Eb daysign (Bold - visually correspond to Main Sign-Superfix pattern; Bold+ltalics - most plausable variants).

\begin{tabular}{|c|c|c|c|c|c|}
\hline $\mathbf{8 . 1 6 . 1 0 . 0 6 . 1 2}$ & $\mathbf{4}$ & Eb & $\mathbf{1 0}$ & Kumk'u $^{\prime}$ & $\mathbf{2 4 . 4 . 3 6 7}$ \\
\hline $\mathbf{8 . 1 6 . 1 3 . 1 7 . 1 2}$ & $\mathbf{4}$ & $\mathbf{E b}$ & $\mathbf{1 0}$ & Yax & $\mathbf{1 4 . 1 1 . 3 7 0}$ \\
\hline $\mathbf{8 . 1 6 . 1 7 . 1 0 . 1 2}$ & $\mathbf{4}$ & Eb & $\mathbf{1 0}$ & Wo & $\mathbf{6 . 6 . 3 7 4}$ \\
\hline 8.16 .18 .05 .12 & 4 & Eb & 10 & Muwan & 21.2 .375 \\
\hline$\underline{\mathbf{8 . 1 7 . 0 1 . 1 6 . 1 2}}$ & $\mathbf{4}$ & Eb & $\underline{\mathbf{1 0}}$ & $\underline{\text { Yaxk }^{\prime} \mathbf{n}}$ & $\underline{\mathbf{1 3 . 9 . 3 7 8}}$ \\
\hline $\mathbf{8 . 1 7 . 0 6 . 0 4 . 1 2}$ & $\mathbf{4}$ & $\mathrm{Eb}$ & $\mathbf{1 0}$ & Keh & $\mathbf{2 1 . 1 2 . 3 8 2}$ \\
\hline 8.17 .09 .15 .12 & 4 & Eb & 10 & Sotz' & 13.7 .386 \\
\hline 8.17 .10 .10 .12 & 4 & Eb & 10 & K'ayab $^{\prime}$ & 30.3 .387 \\
\hline $\mathbf{8 . 1 7 . 1 4 . 0 3 . 1 2}$ & $\mathbf{4}$ & Eb & $\mathbf{1 0}$ & Ch'en $^{\prime}$ & $\mathbf{2 0 . 1 0 . 3 9 0}$ \\
\hline 8.17 .17 .14 .12 & 4 & Eb & 10 & Pop & 12.5 .394 \\
\hline 8.17 .18 .09 .12 & 4 & Eb & 10 & K'ank'in $^{\prime}$ & 27.1 .395 \\
\hline 8.18 .02 .02 .12 & 4 & Eb & 10 & Xul & 19.8 .398 \\
\hline
\end{tabular}




\begin{tabular}{|c|c|c|c|c|c|}
\hline$\underline{8.18 .06 .08 .12}$ & 4 & $\underline{E b}$ & $\underline{10}$ & $\underline{\text { Sak }}$ & 26.11.402 \\
\hline 8.18 .10 .01 .12 & 4 & $E b$ & 10 & Sip & 18.6. 406 \\
\hline 8.18 .10 .14 .12 & 4 & $\mathrm{~Eb}$ & 10 & Pax & 5.3. 407 \\
\hline 8.18 .14 .07 .12 & 4 & $\mathrm{~Eb}$ & 10 & Mol & 25.9 .410 \\
\hline 8.18 .18 .13 .12 & 4 & $\mathrm{~Eb}$ & 10 & Mak & 2.1 .415 \\
\hline 8.19 .02 .06 .12 & 4 & $\mathrm{~Eb}$ & 10 & Sek & 25.7. 418 \\
\hline 8.19 .06 .12 .12 & 4 & $E b$ & 10 & Yax & 1.11. 422 \\
\hline 8.19 .10 .05 .12 & 4 & $E b$ & 10 & Wo & 24.5 .426 \\
\hline 8.19 .11 .00 .12 & 4 & $\mathrm{~Eb}$ & 10 & Muwan & 8.2 .427 \\
\hline 8.19 .14 .11 .12 & 4 & $\mathrm{~Eb}$ & 10 & Yaxk'in & 31.8. 430 \\
\hline 8.19 .18 .17 .12 & 4 & $\mathrm{~Eb}$ & 10 & Keh & 8.12 .434 \\
\hline 9.00 .02 .10 .12 & 4 & $\mathrm{~Eb}$ & 10 & Sotz' & 30.6 .438 \\
\hline 9.00 .03 .05 .12 & 4 & $\mathrm{~Eb}$ & 10 & K'ayab & 17.3. 439 \\
\hline
\end{tabular}

Glyph 31A consists of a main sign with no phonetic complement (which was not necessary in case of this Early Classic mural painting), but it appears clearly with a superfix, which is mostly eroded. Possible Haab months for this glyph would be Wo, Sip, Yaxk'in, Ch'en, Yax, Sak, Keh and Kumk'u. Possible dates therefore shrink to twelve records. According to closer analysis of this Haab date, superfix with little dot on left side looks more like T16 $\operatorname{sing}(<\mathbf{Y A X}>)$ or T58 $(<\mathbf{S A K}>)$.

\section{Probably dates for mural paintings}

Thompson's analysis includes also possible 6 Tun (or more correctly 6 Haab), at position 71, under $5 \mathrm{~Eb}$ daysign, associated with Long Count series. However, he doubts this possibility, because the beginning of 6 tun falls on 9.8.5.0.1 12 Imix 19 Yaxk'in (July 26, $598 \mathrm{CE}$ ), which is also far too late for Structure B-XIII (SMITH 1955:57). This would work, of course, if we agree that the whole calendar line begins with date 12 Imix and not 13 Ik'. This position also cannot record completing of 6 Tun, because these cycles (with winikhaab and pih) always end on Tzolk'in date Ajaw. It is more possible that term wak haab could refer to something else, which is not tied in calendric basis.

If we agree with a hypothesis of Haab date at position 31A, two most probably dates for event in Clause 3 in the inscription will be 8.17.01.16.12 4 Eb 10 Yaxk'in (September 13, 
$378 \mathrm{CE}$ ) and 8.18.06.08.12 $4 \mathrm{~Eb} 10 \mathrm{Sak}$ (November 26, $402 \mathrm{CE}$ ). Chronology for both events is described in Table 3 and 4 . The first possible date is plausible, because it happens couple of months after the famous entrada date. The second possible date is still acceptable, because Teotihuacan influence lasted for almost two centuries (GÓMEZ KOVÁČ 2016:40).

Table 3: Chronology of timeline from Structure B-XIII for year $378 \mathrm{CE}$.

\begin{tabular}{|c|c|c|c|c|c|c|}
\hline 8.17 .01 .15 .02 & 13 & Ik' & 0 & Xul & 14.8. 378 & Beginning \\
\hline+1 & & & & & & $\mathrm{DN}$ \\
\hline 8.17 .01 .15 .0 & 1 & Ak'bal & 1 & Xul & 15.8. 378 & Clause 1 \\
\hline 3 & & & & & & \\
\hline+9 & & & & & & DN \\
\hline 8.17 .01 .15 .12 & 10 & $\mathrm{~Eb}$ & 10 & Xul & 24.8 .378 & Clause 2 \\
\hline+20 & & & & & & $\mathrm{DN}$ \\
\hline 8.17 .01 .16 .12 & 4 & $\mathrm{~Eb}$ & 10 & Yaxk'in & 13.9. 378 & Clause 3 \\
\hline+1 & & & & & & $\mathrm{DN}$ \\
\hline 8.17 .01 .16 .13 & 5 & Ben & 11 & Yaxk'in & 14.9. 378 & Clause 4 \\
\hline+18 & & & & & & $\mathrm{DN}$ \\
\hline 8.17 .01 .17 .11 & 10 & Chuwen & 9 & $\mathrm{Mol}$ & 2.10 .378 & Clause 5 \\
\hline+8 & & & & & & $\mathrm{DN}$ \\
\hline 8.17.01.17.19 & 5 & Kawak & 17 & $\mathrm{Mol}$ & 10.10. 378 & Clause 6 \\
\hline+8 & & & & & & $\mathrm{DN}$ \\
\hline 8.17 .02 .00 .07 & 13 & Manik' & 5 & Ch'en & 18.10. 378 & Clause 7 \\
\hline+1 & & & & & & $\mathrm{DN}$ \\
\hline 8.17 .02 .00 .08 & 1 & Lamat & 6 & Ch'en & 19.10. 378 & \\
\hline+4 & & & & & & $\mathrm{DN}$ \\
\hline 8.17 .02 .00 .12 & 5 & $\mathrm{~Eb}$ & 10 & Ch'en & 23.10 .378 & Clause 8 \\
\hline
\end{tabular}


Table 4: Chronology of timeline from Structure B-XIII for years 402/403 CE.

\begin{tabular}{|c|c|c|c|c|c|c|}
\hline 8.18 .06 .07 .02 & 13 & $\mathrm{Ik}^{\prime}$ & 0 & Xul & 27.10 .402 & Beginning \\
\hline+1 & & & & & & DN \\
\hline 8.18.06.07.03 & 1 & Ak'bal & 1 & Yax & 28.10 .402 & Clause 1 \\
\hline+9 & & & & & & $\mathrm{DN}$ \\
\hline 8.18.06.07.12 & 10 & $\mathrm{~Eb}$ & 10 & Yax & 06.11 .402 & Clause 2 \\
\hline+20 & & & & & & $\mathrm{DN}$ \\
\hline 8.18 .06 .08 .12 & 4 & $\mathrm{~Eb}$ & 10 & Sak & 26.11 .402 & Clause 3 \\
\hline+1 & & & & & & $\mathrm{DN}$ \\
\hline 8.18 .06 .08 .13 & 5 & Ben & 11 & Sak & 27.11 .402 & Clause 4 \\
\hline+18 & & & & & & $\mathrm{DN}$ \\
\hline 8.18.06.09.11 & 10 & Chuwen & 9 & Keh & 15.12. 402 & Clause 5 \\
\hline+8 & & & & & & $\mathrm{DN}$ \\
\hline 8.18.06.09.19 & 5 & Kawak & 17 & Keh & 23.12. 402 & Clause 6 \\
\hline+8 & & & & & & $\mathrm{DN}$ \\
\hline 8.18 .06 .10 .07 & 13 & Manik' & 5 & Mak & 31.12. 402 & Clause 7 \\
\hline+1 & & & & & & $\mathrm{DN}$ \\
\hline 8.18 .06 .10 .08 & 1 & Lamat & 6 & Mak & 01.01 .403 & \\
\hline+4 & & & & & & $\mathrm{DN}$ \\
\hline 8.18.06.10.12 & 5 & $\mathrm{~Eb}$ & 10 & Mak & 05.01 .403 & Clause 8 \\
\hline
\end{tabular}

We have numerous inscriptions, or iconographic scenes, where Teotihuacan style was incorporated or mentioned. Many of these recorded events try to legitimize the power of a current ruler with connection to Teotihuacan. We can see a human figure wearing Teotihuacan style helmet on front of El Zapote Stela 4. The Long Count date of inscriptions is 8.17.2.5.3 5 Ak'bal 1 Kank'in (January 22, $379 \mathrm{CE}$ ), while the inscription of the left side mentions local lord „Bird Head“ as an y-ajaw of kalomte' Sihyaj K'ahk' from Wiin Te'Naah. The purpose of these inscriptions is to legitimize the power of new ruler of El Zapote under the aegis of the foreign overlord (BELIAEV et al. 2017:3). According to the 
chronology of La Sufricaya Mural 7, the dedication event happened at $11 \mathrm{Kib} 14 \mathrm{Mak}$ (8.17.02.04.16), which is January 15, 379 CE. There, events and ceremonies that happened before the dedication event are also mentioned, and whole inscription is ended with information about the arrival of Sihyaj K'ahk' (ESTRADA-BELLI et. al. 2011:31).

As we can see on an example from Xultun murals (Structure 10K2, The Los Sabios group), not only kings or royal family were shown in this type of scenes, but also priests and intellectual specialist, titled as taaj (SATURNO et. al. 2017).

Hieroglyphic inscription in the form of a timeline with recorded events in the range of 71 days has clear connection with depicted scenes above the inscription itself. The dates which were recorded on this timeline don't correspond to any famous event which happened during the entrada and were not found on any other Early Classic monument which deals with the era of Teotihuacan influence. The calendar could be used not only to record the deeds and events of Maya royalty, but also of a noble household (MILLER 2006:65).

This timeline was probably made for the purpose of recording specific events of festival with connection to foreigners from Teotihuacan. It was definitely not meant to be for a public presentation, but only for residents of Structure B-XIII, or generally the whole east plaza of Group B. The question is whether the upper scene represents one-day event, or depicts numerous events, which were therefore recorded on the timeline at the bottom of wall. Unfortunately, the mural painting in Structure B-XIII was not preserved and probably most of it was destroyed even before the excavations of the Carnegie Institution in 1930's. Nonetheless, this type of timeline which was recorded on a stucco wall shows us different view on how Maya scribe could record specific event in opposition to monumental inscriptions. But further analysis, especially of upper part of paintings, will be needed to understand the story of interaction between the Maya and foreigners.

\section{Acknowledgements}

I would like to thank Guido Krempel for some ideas and brief consultation. This work was also supported by VEGA 1/0858/17 and APVV-0864-12. 


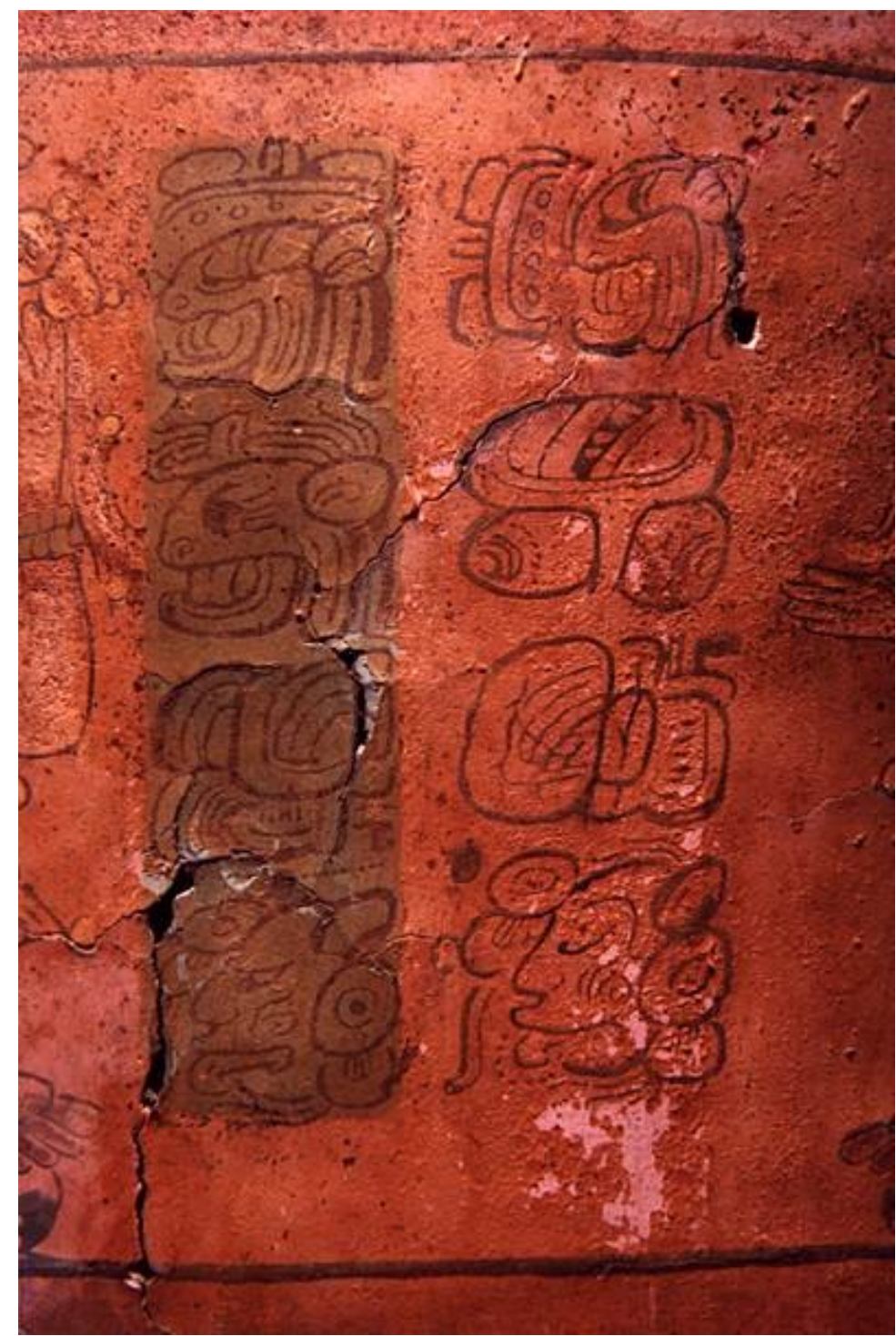

Figure 12: Early Classic calligraphic style of glyphs on painted stucco vessel from Burial A31, Uaxactun. Photo: M. Van Stone 


\section{Bibliography}

BELIAEV, D. - STUART D. - LUIN C.A. (2017): Late Classic Maya Vase with the mention of Sihyaj K'ahk' from the museo VICAL, Casa Santo Domingo, Antigua Guatemala. Mexicon XXXIX (1): 2-4.

BOOT, E. (2009): A Preliminary Classic Maya-English/English-Classic Maya Vocabulary of Hieroglyphic Readings. Mesoweb. Electronic document, http://www.mesoweb.com/resources/vocabulary/Vocabulary-2009.01.pdf, accessed May 10, 2017.

BLACK, S. L. (1990): The Carnegie Uaxactun Project and the Development of Maya Archaeology. Ancient Mesoamerica 1(2), pp. 257-276.

BRASWELL, G. E. (ed.) (2003): The Maya and Teotihuacan. Reinterpreting the Early Classic Interaction. Austin: University of Texas Press.

CARRASCO, D. - JONES, L. SESSIONS, S. (2000): Mesoamerica's Classic Heritage: From Teotihuacan to the Aztecs. Boulder: University Press of Colorado.

COWGILL, G. L. (2003): Teotihuacan and Early Classic Interaction: A perspective from Outside the Maya Region. In Geoffrey E. Braswell (ed.), The Maya and Teotihuacan. Reinterpreting Early Classic Interactions, pp. 315-336, Austin: University of Texas Press.

ESTRADA- BELLI, F. - TOKOVININE, A. - FOLLEY, J. M. - HURST, H. - WARE, G. A. - STUART, D. - GRUBE, N. (2009): A Maya Palace at Holmul, Peten Guatemala and the Teotihuacan "Entrada": Evidence from Murals 7 and 9. Latin American Antiquity 20, pp. 228-259.

ESTRADA- BELLI, F. - TOKOVININE, A. - FOLLEY, J. M. - HURST, H. - WARE, G. A. - STUART, D. - GRUBE, N. (2011): Pintura Mural e Historia en Holmul, La Sufricaya, Guatemala, y las relaciones teotihuacanas con las tierras bajas. In Merideth Paxton and Manuel A. Hermann Lejarazu (eds.), Texto, Imagen e Identidad en la pintura Maya prehispanica. México: Universidad Nacional Autónoma de México.

FAHSEN, F. (1988): A New Early Classic Text from Tikal. Research Reports on Ancient Maya Writing 17. Washington D.C.: Center for Maya Research.

GARTON, J. - TAUBE, K. A. (2017): An Olmec Style Statuette in the Worcester Art Museum Illustration. Mexicon XXXIX (2): 29, 35-40.

GÓMEZ, O. - KOVÁČ, M. (2016): Las relaciones entre Tikal y Uaxactún. Investigaciones actuals. Arqueología Mexicana, Vol. XXIII (137), pp. 38-45.

KETTUNEN, H. - HELMKE, CH. (2014): Introduction to Maya Hieroglyphs. XiX European Maya Conference. Bratislava: Wayeb.

DOI: 10.1515/eas-2017-0009 @ University of SS. Cyril and Methodius in Trnava. All rights reserved. 
KOVÁČ, M. - DESPRAT, A. - PALLÁN GAYOL, C. (2015): New Stucco Masks from Uaxactun: Interpretation, Conservation and Documentation of Extraordinary Preclassic Maya Art. In. Hulínek, D., Bonatz, D., Kováč, M. (eds.), Archaeology on Three Continents 2006-2011, pp. 125-142, SAHI: Bratislava.

KOVÁČ, M - KARLOVSKÝ, V. (2015): New Maya Observatory Identified in Uaxactún, Guatemala. In. Hulínek, D., Bonatz, D., Kováč, M. (eds.), Archaeology on Three Continents 2006-2011, pp. 125-142, SAHI: Bratislava.

KOVÁČ, M. - JOBOVÁ, E. - KREMPEL, G. (2016): The Legacy of Early Maya King: Text, Imagery, and Ritual Contexts of a Late Preclassic Cache from Structure H-XVI, Uaxactun, Guatemala. Mexicon XXXVIII (1): 9-29.

LACADENA GARCÍA-GALLO, A. (2004): The Glyphic Corpus from Ek' Balam, Yucatán, México. FAMSI Reports, Available here: http://www.famsi.org/reports/01057/01057LacadenaGarciaGallo01.pdf (May, 2017).

LAPORTE, J. P. (2003): Architectural Aspects of Interaction between Tikal and Teotihuacan during the Early Classic Period. In Geoffrey E. Braswell (ed.), The Maya and Teotihuacan. Reinterpreting Early Classic Interactions, pp. 197-234. Austin: University of Texas Press.

MARCUS, J. (2003): The Maya and Teotihuacan. In Geoffrey E. Braswell (ed.), The Maya and Teotihuacan. Reinterpreting Early Classic Interactions, pp. 337 - 356. Austin: University of Texas Press.

MARTIN, S. - GRUBE, N. (2008): Chronicle of the Maya Kings and Queens: Deciphering the Dynasties of the Ancient Maya. London: Thames and Hudson.

MILLER, M. E. (2006): Maya Painting, in a Major and Minor Key. Anales del Instituto investigaciones Estéticas XXVIII (89), pp. 59-70.

PROSKURIAKOFF, T. (1993): Maya History. Austin: University of Texas Press.

Rice, P. M. (2007): Maya Calendar Origins. Monuments, Mythistory, and the Materialization of Time. Austin: University of Texas Press.

SATURNO, W. - ROSSI, F. - STUART, D. - HURST, H. (2017): A Maya Curia Regis: Evidence for a Hierarchical Specialist Order at Xultun, Guatemala. Ancient Mesoamerica 28(2), pp. 1-18.

SMITH, L. A. (1950): Uaxactun, Guatemala: Excavations of 1931-1937. Washington D.C.: Carnegie Institution of Washington.

SMITH, R. E. (1955): Ceramic Sequence at Uaxactun, Guatemala. Volume II. New Orleans: Middle American Research Institute Tulane University. 
STONE, A. - ZENDER, M. (2011): Reading Maya Art. A Hieroglyphic Guide to Ancient Maya Painting and Sculpture. London: Thames \& Hudson.

STUART, D. (2000): The Arrival of Strangers: Teotihuacan and Tollan in Classic Maya History. In David S. Carrasco et. al. (eds.), Mesoamerica's Classic Heritage: Teotihuacan to the Aztecs, pp. 465-513. Boulder: University Press of Colorado.

THOMPSON, J. E. S. (1962): A Catalogue of Maya Hieroglyphs. University of Oklahoma Press.

TOKOVININE, A. - SAFRONOV, A. (2016): On the Same Team - Talking Hierarchy in Classic Maya Texts. Workshop Handbook European Maya Conference. Moscow: Wayeb.

URQUIZÚ, M. - HURST, H. (2011): The Murals of San Bartolo: A Windows into the Art and Cosmovision of Precolumbian Man. PARI Journal 12(2), pp. 8-13.

VAIL, G. - AVENI, A. (2004): Maya Calendars and Dates: Interpreting the Calendrical Structure of Maya Almanacs. In Vail and Aveni (eds.), The Madrid Codex. New Approaches to Understanding an Ancient Maya Manuscript, Boulder: University Press of Colorado.

VOß, A. - EBERL, M. (1999): Ek Balam: A New Emblem Glyph from the Northeastern Yucatán. Mexicon XXI (6), pp. 124-131.

ZENDER, M. - SKIDMORE, J. (2012): Unearthing the Heavens: Classic Maya Murals and Astronomical Tables at Xultun, Guatemala. Mesoweb Reports. Electronic document: www.mesoweb.com/reports/Xultun.pdf. Accessed March, 2017. 